\title{
The Relationship Between Park Satisfaction, Place Attachment and Revisit Intention in Neighborhood Parks with Physical Activity Facilities
}

\author{
Hüseyin Çevik ${ }^{1}$ \\ ${ }^{1}$ Faculty of Sport Science, Eskisehir Technical University, Eskisehir, Turkey \\ Correspondence: Hüseyin Çevik, Faculty of Sport Science, Eskisehir Technical University, Eskisehir, Turkey. \\ E-mail: huseyincevik@eskisehir.edu.tr
}

Received: December 30, 2019 Accepted: February 3, 2020 Online Published: March 1, 2020

doi:10.5539/jel.v9n2p178 URL: https://doi.org/10.5539/jel.v9n2p178

This study is the developed form of the paper presented in 2nd International Congress on Recreation and Sport Management, 11-14 April 2019, Bodrum, Muğla, Turkey.

\begin{abstract}
The urban population is increasing day by day, threatening human health. Neighborhood parks in which people can participate in physical activities have an important place in reducing the negative effects of urban life. However, not much is known much about factors such as "park satisfaction" and "place attachment", which may play a role in the visitors' participation in and continuation of physical activity in neighborhood parks, or the relationship between these factors. The purpose of this study was thus to examine the relationship between park satisfaction, place attachment and revisit intention. The data were obtained using the convenience sampling method from 357 park visitors who visited a park for physical activity. The methodological principles of structural equation modeling were used to test the conceptual model based on the literature review. According to the results, park satisfaction had a positive and significant effect on park attachment. In addition, park attachment played a mediating role between satisfaction and revisit intention. As a result, a theoretical and comprehensive model that revealed the relationship between park satisfaction, park attachment and revisit intention was developed. It is thought that the results will guide local governments, managers responsible for parks and park designers in maintaining open-air recreation facilities and services in urban areas.
\end{abstract}

Keywords: neighborhood park, satisfaction, place attachment, physical activity, revisit intention

\section{Introduction}

Neighborhood parks are often equipped with open-air fitness areas and facilities for physical activities such as walking, jogging, cycling, in addition to being places where city residents can spend their leisure time engaging in various other activities (Bedimo-Rung, Mowen, \& Cohen, 2005; Cohen et al., 2007). Thanks to specific advantages, such as their easy and free access, they promote an active life for visitors from different social and economic backgrounds, and encourage them to participate in regular physical activities (Baran et al., 2014). Active life and regular physical activity increases individuals' quality of life and reduces morbidity and mortality rates by minimizing the risk of heart diseases, diabetes, high blood pressure, colon cancer, feelings of depression/anxiety, while also helping with weight loss and the building and maintaining of healthy bones, muscles, and joints (Bedimo-Rung et al., 2005; Nantel, Mathieu, \& Prince, 2011).

Having easy access to parks, their quality and convenience (Cohen et al., 2007), as well as the visitors' positive experiences and the resulting satisfaction (Uysal, Eser, \& Birkan, 2002) play an important role in individuals' regular participation in physical activities in these areas. Parks facilitate social interaction and allow visitors to test their skills and stay healthy by participating in these physical activities, which in turn affects their level of satisfaction (Halpeny, 2006). According to Zenker and Gallon (2010), place satisfaction has a strong effect on people's wish to stay longer in a place. Therefore, it might be concluded that satisfaction with a particular park plays an important role in people participating in physical activities regularly in these parks and staying healthy.

Visitor satisfaction significantly contributes to the creation of an emotional bond with places; especially if the 
place is an open recreational area like a park (Ramkissoon \& Mavondo, 2015). This emotional bond between people and parks is called "place attachment" in the literature focusing on the psychology of leisure, tourism and the environment (Lai, Hsu, \& Nepal, 2013). Place attachment refers to the value individuals ascribe to a particular place and how they associate this place with themselves. In other words, place attachment can be defined as an emotional and social bond an individual creates with a particular place (Low \& Altman, 1992). Previous research shows that place attachment has an important effect on revisit intention (Lee, Kyle, \& Scott, 2012; Loureiro, 2014; Plunkett, Fulthorp, \& Paris, 2019). Accordingly, place attachment, which affects people's quality of life and encourages them to participate in physical activities (Kuo, Bacaicoa, \& Sullivan, 1998), might have a significant effect in whether people continue to do physical activities. Examining the relationship between park satisfaction, place attachment and revisit intention is thus very important.

Place attachment has been a topic of interest in studies conducted in various different contexts (Chen, Hall, Yu, \& Qian, 2019; Fu, Yi, Okumuş, \& Jin, 2019; Han, Kim, Lee, \& Kim, 2019; Rastbod \& Aflatounian, 2017). It has been examined in relation to national parks (Halpenny, 2006; Ramkissoon \& Mavondo, 2015; Ramkissoon, Smith, \& Kneebone, 2014), urban parks (Lee \& Shen, 2013; Plunkett, Fulthorp, \& Paris, 2019) and neighborhood parks (Strzelecka, Sorensen, \& Wicks, 2013). However, the limited number of studies on neighborhood parks and lack of empirical studies examining parks with physical activity facilities imply that there is a need to examine this issue in more detail. This study thus aims to examine the relationship between park satisfaction, place attachment and revisit intention for parks with physical activity facilities. Revealing this relationship will help local administrators, city planners and park managers to run and improve parks effectively. In addition, the study will contribute to understanding the factors affecting visits to parks with physical activity facilities and the relationships among them, so that it might be easier to create a healthy urban society.

\section{Theoretical Frameworks and Hypothesis}

\subsection{Park Satisfaction}

Satisfaction is defined as the total psychological outcome of a visitor's experience of a particular place at a particular time (Tian-Cole, Crompton, \& Willson, 2002). Park satisfaction refers to the outcome of the perceived quality of a park regarding the environment that meets a visitor's needs through its physical features and the services it provides (Ramkissoon, Smith, \& Weiler, 2013). Satisfaction may result in revisiting, emphasizing the superior features of the place, positive word-of-mouth, recommending the place to others and a willingness to stay longer (Lam \& Ozorio, 2012; Theodorakis, Alexandris, Tsigilis, \& Karvounis, 2013). According to Kyle, Mowen and Tarrant (2004), the presence of opportunities for people to enjoy their favorite activities increases their satisfaction with a place. Therefore, when neighborhood parks are equipped with facilities to allow users to engage in healthy activities such as physical exercise, their park satisfaction levels might increase accordingly.

\subsection{Place Attachment}

Place attachment is defined as the emotional and symbolic relationship an individual establishes with a particular place (Hidalgo \& Hernandez, 2001; Williams \& Vaske, 2003). People generally develop attachment to a place when they give it meaning through social interactions and the emotional bond established (Milligan, 1998). "Attachment theory" (Bowlby, 1969) suggests that interactions between people and places lead to the development of place attachment (Tuan, 1980).

There is a growing consensus in the literature that place attachment has a multi-dimensional structure (Chen, Dwyer, \& Firth, 2014; Ramkissoon et al., 2013), although some researchers define this structure as a two-dimensional one involving both place dependence and place identity (Williams \& Roggenbuck, 1989; Williams \& Vaske, 2003). According to some researchers, place attachment can be conceptualized as having the following dimensions: place dependence (Williams, Patterson, Roggenbuck, \& Watson, 1992), place identity (Prohansky, 1978), social bonding (Ramkissoon et al., 2013) and, more recently, place affect (Halpenny, 2010). Similarly, Kyle, Graefe and Manning (2005) examined place attachment through the dimensions of place identity, place dependence and social bonding dimensions. Recent studies on recreational activities also support the presence of these dimensions. For instance, Budruk and Stanis (2013) used these dimensions in their study which examined the relationship between place attachment and recreation experience preference. In addition, Plunkett et al. (2019) used these three dimensions in their study on the relationship between behavioral loyalty and place attachment for urban park visitors. Finally, Fulthrop and Plunkett (2019) examined the participants' place attachment to special recreational events organized in municipal parks by using a model consisting of these dimensions. In the light of previous studies focusing on recreation, the current study measures place attachment through the dimensions of place dependence, place identity and social bonding.

Place identity, one of the dimensions mentioned above, refers to an emotional/symbolic bond with a particular 
place and the individual's identity in relation to the physical world (Proshansky, 1978). It contains both cognitive and affective elements, and is an important part of one's entire sense of identity (Zenker \& Rütter, 2014). Places, with their cultural significance, offer individuals an opportunity to identify themselves with distinctive environments (Ramkissoon et al., 2013a) and express their sense of identity (Budruk et al., 2009). Place dependence means "to what extent a particular place meets an individual's needs". In other words, if a place fails to meet an individual's needs, they might develop attachments to another place that meets such needs (Stokols \& Shumaker, 1981). Therefore, parks which address an individual's need for physical activity might affect their dependence on that particular park and make it easier for them to continue engaging in that physical activity. Another dimension is social bonding. Sometimes, a particular place is considered special because it facilitates interactions among people and helps them to establish a social bond with others or join a particular group (Budruk \& Stanis, 2013; Scannell \& Gifford, 2010). The interaction of people who visit parks for physical activities with the park itself might facilitate their social bonds with other people.

\subsection{The Relationship Between Park Satisfaction and Place Attachment}

The relationship between park satisfaction and place attachment is an issue discussed in various fields. Many studies reveal a relationship between place satisfaction and place attachment (Prayag \& Ryan, 2012; Ramkissoon et al., 2013; Yuksel, Yuksel, \& Bilim, 2010). Research has revealed a positive correlation between the two concepts (Ramkissoon et al., 2013) and shown that place satisfaction is a premise of place attachment, or vice versa (Prayag \& Ryan, 2012; Stedman, 2002). Environmental psychologists have suggested that an individual might be satisfied with a particular place without feeling an attachment to it (Petrick, Backman, \& Bixler, 1999). This finding was also supported by the study conducted by Mesc and Manor (1998). However, Lee and Allen's (1999) study showed that there was no positive correlation between satisfaction with coastal tourism destinations in South Carolina and place attachment. According to George and George (2004), satisfying experiences result in high levels of place attachment. When the topic was examined in terms of parks, Halpenny (2006) reported that satisfaction with nature, the social environment and the environment where an activity is carried out had a positive influence on place attachment. A similar finding was stated by Ramkissoon, Smith and Kneebone (2014) in their study on national parks. Therefore, the following hypothesis was proposed, on the assumption that the relationship between the two concepts might also be observed in individuals visiting parks to engage in physical activity.

\section{$H_{1}$ Park satisfaction has a positive and direct effect on place attachment}

\subsection{The Relationship Between Place Attachment and Revisit Intention}

The intention to visit a place has been explained by inner social psychological factors such as attachment to the place (Hailu, Boxall, \& McFarlane, 2005). Psychologists and sociologists emphasize that place attachment is an important source of motivation for people to revisit a place and spend their time there (Manzo \& Perkins, 2006). According to Moulay, Ujang, Maulan and Ismail (2018), the process of becoming attached has an effect on the emergence of this behavior. This relationship has been examined by different researchers. For instance, Prayag and Ryan (2012) found a positive relationship between place attachment and revisiting in their study focusing on tourists. This finding was also supported by Loureiro (2014), who found that place attachment has a positive effect on revisit intention. Therefore, the following hypothesis was proposed on the assumption that the relationship between the two concepts might also be observed in individuals visiting parks to engage in physical activity.

\section{$\mathrm{H}_{2}$ Place attachment has a positive and direct effect on revisit intention.}

\subsection{The Effect of Park Satisfaction on Revisit Intention}

The tendency to revisit a particular place due to satisfaction has been supported by many studies (Brown, Smith, \& Assaker, 2016; Dayour \& Adongo, 2015; Kim, Son, Lee, \& Park, 2011). In the tourism context, Chen and Tsai (2007) suggested that satisfied visitors are more likely to revisit a particular tourist destination. In another study by Brown et al. (2016), they found that satisfied tourists have a positive attitude towards a place and have a greater intention to revisit the destination in the future. In the contexts of sports, it was found that athletes often revisit a place where a sports event has been organized (Shonk \& Chelladural, 2008). The positive and direct effect of place satisfaction on revisiting was also observed in Prayag and Ryan's (2012) study. Based on the above-mentioned findings, the following hypothesis was proposed:

\section{$\mathrm{H}_{3}$ Park satisfaction has a positive and direct effect on revisit intention.}

\subsection{The Role of Place Attachment Between Satisfaction and Revisit Intention}

Recent studies in the literature have revealed the mediating role of place attachment among different variables. 
The study conducted by Hosany, Prayag, Van Der Veen, Huang and Deesilatham (2017) supports the mediating role of place attachment between emotions and the intention to recommend this place to others. Song, Kim and Yim (2017), in their study conducted with golf tourists, found that place attachment has a mediating role in the relationship between "destination image" and revisit intention. Similarly, the findings of Hu, Tuou and Liu's (2019) study also revealed the mediating role of place attachment. The mediating role of place attachment between place satisfaction and revisit intention was examined by Lee et al. (2012). According to the findings of their study, place attachment plays a mediating role between "festival satisfaction" and "destination attachment". Assuming that such a relationship might also be observed in a group of people who visit neighborhood parks to engage in physical activity, the following hypothesis was proposed:

\section{$\mathrm{H}_{4}$ Place attachment mediates in the relationship between park satisfaction and revisiting.}

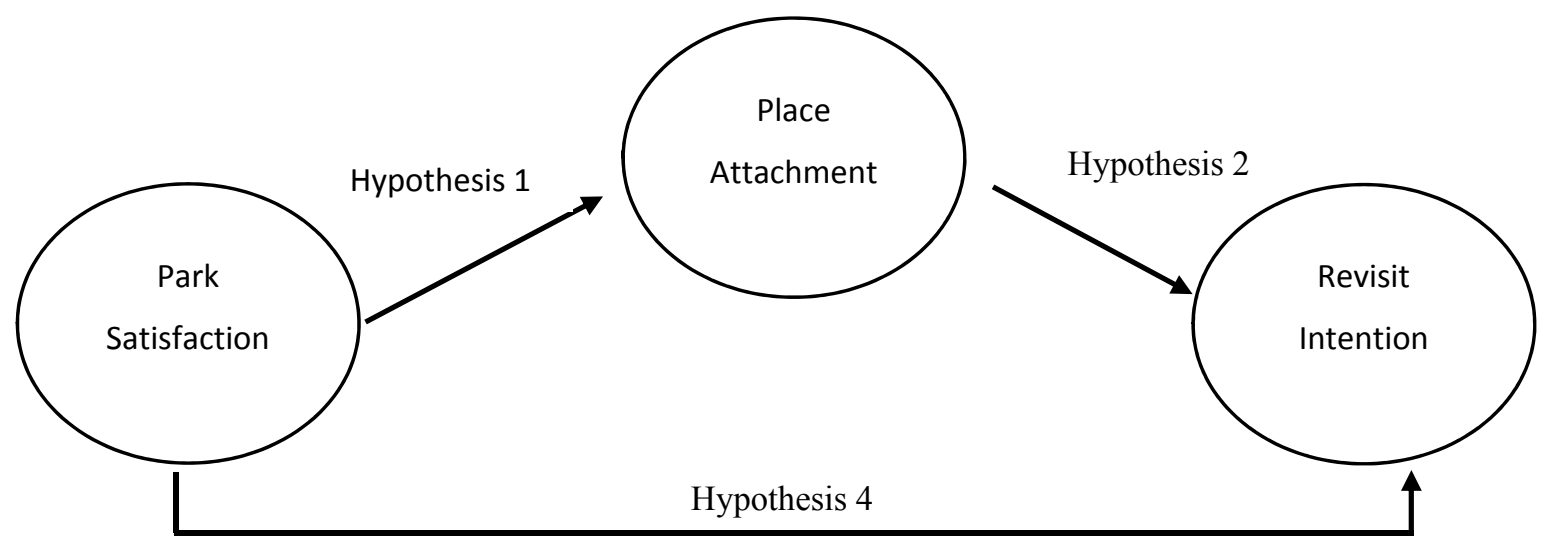

Hypothesis 3

Figure 1. Conceptual model

\section{Method}

\subsection{Participants and Procedures}

The data for the study were collected from the participants who visited Kırımlığlu, Kanlı Kavak, Bestekar Hacı Arif Bey and Dedekorkut parks, which are located in the city center of Eskişehir, Turkey, to do physical activities. 357 participants, who were determined using the convenience sampling method, were included in the study. Data were collected in March, April and May 2019 through questionnaires administered face-to-face by the researcher and four students from the Faculty of Sport Sciences working part-time who were experienced in conducting questionnaires. The author informed the students about the purpose of the study, the questionnaire and the process of applying the questionnaire before the data collection. In addition, interactive training was given to the students, using them as both interviewers and interviewees.

The percentage of male participants was $44.3 \%(\mathrm{n}=158)$ and the percentage of female participants was $55.7 \%$ $(n=199)$. The majority of the group was between the ages of $18-35-$ a percentage of $39.5 \%(n=141)$. The percentage of those with an associate/undergraduate degree was $61.9 \%(\mathrm{n}=221)$. According to the profession, the highest rate of participation was among the actively nonworking group (student, housewife, retiree) $33.6 \%$ $(\mathrm{n}=120)$. According to monthly income, most of the participants $(23.8 \%)$ had an income of 1600 Turkish Lira or lower. Most of the participants (54.0\%) visit the park 1-2 times a week. During the visit, most of the participants stayed in the park 61-90 min, with $34.2 \%(\mathrm{n}=122)$.

\subsection{Instrument}

The questionnaire used in this study consisted of two parts. The first part measured respondents' perception of place satisfaction, place attachment and revisit intention. All items were measured on a five-point Likert scale ranging from 1 ("strongly disagree") to 5 ("strongly agree"). The second part asked about the respondents' demographic information (gender, age, educational level, profession, income, visit frequency and length of stay).

Place attachment was measured through the Place Attachment Scale developed for the recreational field by Kyle et al. (2005). To assess satisfaction, the three statements used by Oliver (1980) and Hellier, Geursen, Carr and 
Rickard (2003), in their research were employed. To evaluate revisit intention, the study used three items from the study by $\mathrm{Wu}, \mathrm{Li}$ and $\mathrm{Li}$ (2018).

The items in the assessment tool were translated the using reverse translation. They were first translated from English to Turkish. Then, two different translators performed a reverse translation from Turkish to English (Banville, Desrosiers, \& Genet-Volet, 2000). This process involved four scholars fluent in both languages and with experience in recreation and park. Then, the translators and researchers met and compared the items with the originals. They made some minor amendments for the sample of park visitors. The researchers then conducted a content analysis of the items in terms of their clarity for the Turkish population. A sample of fifty individuals was randomly selected from the visitors of Dedekorkut park located in Eskisehir city center. At this stage, all items were accepted for the final data collection.

\subsection{Data Analyses}

A structural equation model (SEM) was used in the data analysis. A two-step approach was applied while testing this theoretically developed model (Anderson \& Gerbing, 1988). First, measurement model was tested, which was followed by the testing of the structural model. Measurement model was confirmed through Confirmatory Factor Analysis (CFA). Next, structural model was used to examine hypotheses proposed for the structures. Convergent and discriminant validity analyses were done for validity calculations. The internal consistency of the constructs was measured through composite reliability (CR). The average variance extracted (AVE) was calculated for convergent validity. The correlations between factors were analyzed for the discriminant validity (Hair, Black, Babin, \& Anderson, 2013).

The appropriateness of the data to both the measurement and structural models was evaluated by fit indices. In addition to the chi-square, Root Mean Square Error of Approximation (RMSEA) and Standardized Root Mean Square Residual (SRMR) and the Comparative Fit Index (CFI) and Tucker-Lewis Index (TLI) were used. Chi-square by degrees of freedom values for acceptable level should be less than 3.0 (Kline, 2011), CFI and TLI indexes should exceed .90 (Browne \& Cudeck, 1993), RMSEA values should be equal or less than .08, and SRMR should be less than .05 for acceptable fit (Hair et al., 2013).

\section{Results}

\subsection{Measurement Model}

The hypotheses of the study were tested using the SEM analysis Program. Since the data displayed normal distribution, a covariance matrix was formed using the Maximum Likelihood calculation method. First, the measurement model, which included the variables of park satisfaction, place identity, place dependence, social bonding, and revisit intention was tested. According to the analysis, the following calculations were obtained: $\mathrm{x} 2 / \mathrm{df}=3.287$, RMSEA $=.080, \mathrm{SRMR}=.048, \mathrm{CFI}=.925, \mathrm{TLI}=.908$. Since the $\mathrm{x} 2 / \mathrm{df}$ value was higher than the threshold of 3.0, the modifications suggested by the analysis program were revised. The suggested modification between items 1 and 2 (53.011) under the "social bonding" dimension was made and later reanalyzed accordingly. The goodness of fit values obtained from the analysis $(\mathrm{x} 2 / \mathrm{df}=2.832$; RMSEA $=.072, \mathrm{SRMR}=.043$, $\mathrm{CFI}=.940$, TLI $=.926$ ) confirmed that the suggested model had a good fit and was acceptable. The factor loadings of the items were confirmed to exceed the threshold of .50 at the significant level, as seen in Table 1 (Hair et al., 2013). The CR values of the factors were over .60 (Bagozzi \& Yi, 1988; Hair et al., 2013) and the AVE values were over .50 (Fornell \& Larcker, 1981), except for the social bonding factor (.355) (see Table 2). According to Hatcher (1994), when the CR is acceptable, a marginally low value of the AVE can be accepted. Therefore, we can say that the convergent validity of the measurement model was acceptable. 
Table 1. Factor loadings and Cronbach's alpha values

\begin{tabular}{ll}
\hline Factors & Factor Loading \\
\hline Park Satisfaction( $\alpha=.873)$ & .835 \\
All things considered, I feel good about my decision to doing physical activity at this park. & .834 \\
Overall, I am satisfied with the resort. & .834 \\
Considering all my experience with this park, my choice to doing physical activity at this park was a wise one. & .697 \\
Place identity ( $\alpha=.871)$ & .878 \\
This park means a lot to me. & .794 \\
I am very attached to this park. & .820 \\
I identify strongly with this park. & .811 \\
I feel commitment to this park. & .861 \\
Place dependence $(\alpha=.868)$ & .809 \\
I enjoy doing physical activity along this park more than any other park. & .709 \\
I get more satisfaction out of visiting this park than from visiting any other park. & .549 \\
Doing physical activity here is more important than doing physical activity in any other place. \\
I wouldn't substitute any other park for the physical activity I do here. & .520 \\
Social bonding ( $\alpha=.717)$ & .698 \\
I have a lot of fond memories about the this park. & .604 \\
I have a special connection to this park and the people who doing physical activity here. & .766 \\
I don't tell many people about this trail. & .851 \\
I do bring my children or friends to this park. & .733 \\
Revisit Intention $(\alpha=.813)$ & \\
If I could, I would come to this theme park again. & \\
I always consider this theme park to be the first one choice. & \\
I have a strong intention to visit this park again. &
\end{tabular}

Correlation values between the constructs were analyzed for discriminant validity (See Table 2). It was detected that the relationships between the constructs were significant at the level of $p<.01$ and did not exceed the threshold of .85 (Kline, 2011). For the reliability of the assessment, the Cronbach's alpha internal consistency coefficient was calculated. The Cronbach's alpha coefficients of the factors ranged from .717 to .873 (see Table $1)$.

Table 2. The values of CR, AVE and, correlations among all constructs

\begin{tabular}{llllllll}
\hline Variables & AVE & CR & PS & PI & PD & SB & RI \\
\hline PS & .696 & .872 & - & & & & \\
PI & .639 & .875 & $.553^{* *}$ & - & & & \\
PD & .639 & .875 & $.590^{* *}$ & $.619^{* *}$ & - & & \\
SB & .355 & .685 & $.605^{* *}$ & $.583^{* *}$ & $.605^{* *}$ & - & \\
RI & .616 & .827 & $.727^{* *}$ & $.538^{* *}$ & $.549^{* *}$ & $.580^{* *}$ & - \\
\hline
\end{tabular}

Note. $\mathrm{PS}=$ Park Satisfaction; PI=Place Identity; $\mathrm{PD}=$ Place Dependence; $\mathrm{SB}=$ Social Bonding; $\mathrm{RI}=$ Revisit Intention. ${ }^{* *}$ Correlation is significant at 0.01 level.

\subsection{Structural Model}

Following the verification of the measurement model, structural analysis was conducted. The results of the analysis are displayed in Table 3. First, the effect of park satisfaction on revisit intention was analyzed in order to test $\mathrm{H} 3$. According to the SEM, it was found that park satisfaction predicts revisit intention $(\beta=.863, \mathrm{p}<.001)$, which confirmed $\mathrm{H} 3$.

In order to test other hypotheses, a separate model was formed in which place attachment is a mediating variable (See Figure 2). According to the results, it was found that park satisfaction predicts place attachment $(\beta=.813$, $\mathrm{p}<.001$ ), which confirms $\mathrm{H}_{1}$. Similarly, the effect of mediating variable place attachment on revisit intention was found to be significant $(\beta=.321, p<.001)$, which confirms $\mathrm{H}_{2}$. However, when mediating variable place attachment was included in the model, path coefficient from park satisfaction to revisit intention was still significant $(\beta=.594, \mathrm{p}<.001)$. Place attachment along with park satisfaction accounts for $76 \%$ of the variation in revisit intention. Since goodness of fit indexes calculated in the path analysis are within the acceptable limits, the model can be said to have a good fit and acceptable ( $2 / \mathrm{df}=2.783$; RMSEA $=.071$, SRMR $=.043, \mathrm{CFI}=.940$, $\mathrm{TLI}=.928)$. 


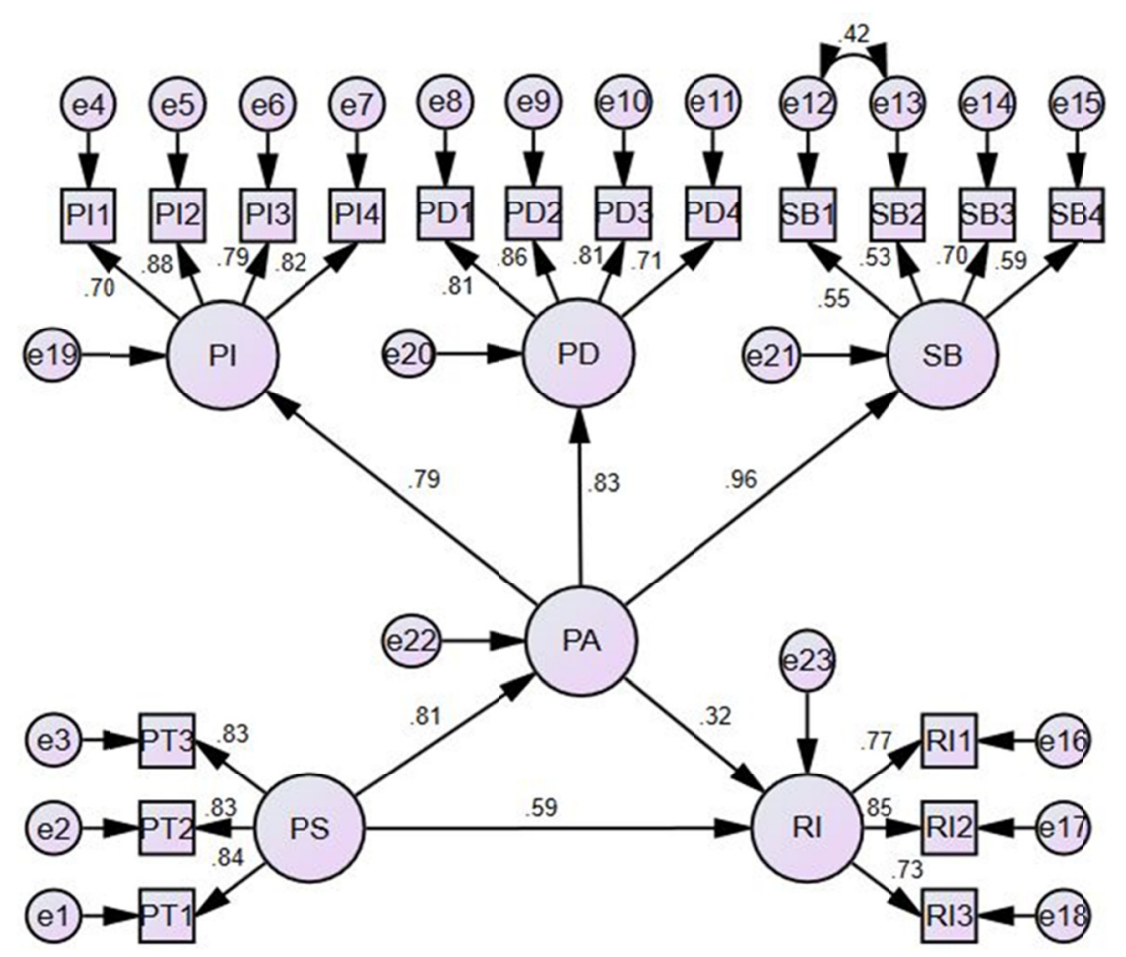

Figure 2. Structural model

A path analysis based on bootstrap method was made in order to test whether place attachment has a mediating role in the relationship between park satisfaction and revisit intention. In this bootstrap analysis, 5000 samples option was preferred. In this type of analysis, the values obtained within $95 \%$ confidence interval should not be zero (Hair, Hult, \& Ringle, 2016). According to Bootstrap results, park satisfaction has a significant effect on revisit intention through place attachment $(\beta=.261, \mathrm{p}<.05,95 \%$ CI $[.09, .46])$. Lower and upper Bootstrap values do not include zero. These results reveal place attachment's mediating role in the relationship between park satisfaction and revisit intention, which confirms $\mathrm{H}_{4}$.

Table 3. Results of structural equation modelling

\begin{tabular}{|c|c|c|c|c|c|c|c|}
\hline \multirow[t]{3}{*}{ Relationship } & \multirow[b]{3}{*}{ Std. $R^{2}$} & \multirow[b]{3}{*}{ S.E. } & \multicolumn{2}{|c|}{ Bootstrap } & \multirow[b]{3}{*}{$\mathrm{t}$} & \multirow[b]{3}{*}{$\mathrm{p}$} & \multirow[b]{3}{*}{ Results } \\
\hline & & & $95 \% \mathrm{CI}$ & & & & \\
\hline & & & Lower & Upper & & & \\
\hline $\mathrm{PS} \rightarrow \mathrm{RI}$ & .594 & .047 & .341 & .805 & 14.019 & $.000 * *$ & Supported \\
\hline $\mathrm{PA} \rightarrow \mathrm{RI}$ & .321 & .100 & 116 & .553 & 3.337 & $.000 * *$ & Supported \\
\hline $\mathrm{PS} \rightarrow \mathrm{PA} \rightarrow \mathrm{RI}$ & .261 & .071 &, 095 & .460 & 6.242 & $.000 * *$ & Supported \\
\hline
\end{tabular}

Note. $\mathrm{PS}=$ Park Satisfaction, $\mathrm{PA}=$ Place Attachment, $\mathrm{RI}=$ Revisit Intention.

\section{Discussion}

Based on the proposed relationship found in the literature, this study examined the effect of park satisfaction on place attachment and revisit intention for people who visited parks for the purpose of physical activity. The results showed that satisfaction with park visits has considerable influence on place attachment and revisit intention. Additionally, the results revealed that place attachment has a mediating role between park satisfaction and revisit intention.

One of the significant findings of the study is that park satisfaction has an effect on place attachment. This finding is consistent with the results of the study by Ramkissoon et al. (2014), in which they found that visitor satisfaction is the premise for place attachment. Similarly, Xu and Zhang (2016) and Ramkissoon and Mavondo (2015) also found similar results. The literature shows that there might be a linear relationship between satisfaction and place attachment or vice versa (Prayag \& Ryan, 2012; Stedman, 2002). The present study makes an important contribution to the discussions in the literature by revealing that the satisfaction of people who visit 
parks for physical activities has an effect on place attachment.

Another important finding of the study is the positive and linear relationship between place attachment and revisit intention. This finding is consistent with the findings of the study by Loureiro (2014); however, it contradicts those of the study by Han et al. (2019), in which they examined the effects of place attachment on behavioral intention. Previous studies suggest that place attachment is an important premise of revisit intention (Yüksek et al., 2010; Lee et al., 2012). Therefore, this study contributes to the literature by also reporting that place attachment is a premise of revisit intention and there is a relationship between these two structures for people who visits parks for the purpose of physical activity.

The study examines the relationship between park satisfaction and revisit intention. The results revealed a positive relationship between park satisfaction and revisit intention. This finding is consistent with the study by Abou-Shouk, Zoair, Barbary and Hewedi (2018), in which they found that satisfaction with a particular destination has effects on tourists' revisit intention. According to Son and Lee (2011), satisfaction is an indication of revisit intention. Therefore, it can be concluded that the park satisfaction of those visiting a park for the purpose of physical activity might be an important indication of revisit intention.

According to the analysis of the model institutionally suggested in the study, place attachment has a mediating role between satisfaction and revisit intention. This finding is consistent with the finding of the study by Lee et al. (2012), which was carried out with festival participants, as well the study by Isa, Ariyanto and Kiumarsi (2019), which examined the mediating role of place attachment between revisit intention and environmental characteristics for tourists visiting Batam Island in Indonesia. A similar result was found in the study conducted by Su, Hsu, Huang and Chang (2018), which was conducted with sport tourists participating in a triathlon. According to the results of the study, place attachment has a mediating role between sport tourists' level of satisfaction with environmental features and revisit intention. Therefore, the current study contributes to the literature by reporting the mediating role of place attachment between the satisfaction of those visiting a park for the purpose of physical activity and revisit intention.

\section{Manageral Implication}

In addition to its contribution to the literature, this study provides valuable information for local administrations, city planners and park managers related to looking after parks with physical activity facilities. According to the results of the study, park satisfaction has an effect on place attachment. Stedman (2002) states that a satisfactory experience in a particular place is due to the characteristics of the place, which creates a bond between visitors and this specific location. With regard to parks with physical activity facilities, their accessibility and closeness to one's home are among the important factors here, especially for adults (Cohen et al., 2007). On the other hand, the significant factors for young people are the presence of active recreation facilities and programs, the appearance and size of the park, its quality and how well it is maintained, and whether their friends also go there (Loukaitou-Sideris \& Sideris, 2010). In addition, safety, aesthetic features and comfort are other factors that encourage people to visit a particular park (McCormack, Rock, Toohey, \& Hignell, 2010). Therefore, park managers should take the factors mentioned above into consideration to ensure and sustain public participation in physical activities. It is recommended that parks be designed with jogging tracks, open-air fitness stations and other facilities for specific activities such as yoga, tai chi etc., or that existing ones be improved accordingly. In this way, visitors are more likely to be satisfied with parks and the bonds they feel with them will be strengthened, which may help park managers run their parks more effectively and improve their existing services (Ryan, 2006).

People visit a certain place because they have special memories of, and social and emotional bonds with it, and because it is a meaningful place for them. Therefore, park managers should provide visitors with an environment that allows them to create memories and socialize with others. One way to achieve this is to offer special programs to bring visitors together to do physical activities and help them socialize in different ways. Special activities offered in a park strengthen peoples' bonds with this particular place (Fulthorp \& Plunkett, 2019). When we consider the fact that place attachment influences revisit intention, it is recommended that local administrations and park managers provide visitors with various options to guarantee that they will revisit parks to engage in physical activities.

According to the United Nations (2016), 54.5\% of the world's population lives in cities. This figure is expected to rise to 60 per cent in 2030. The increasing urban population pose threats to human health for a variety of reasons, so neighborhood parks play an important role in eliminating factors which threaten human health or in reducing their effects. The presence of facilities for physical activity is becoming ever more important in creating a healthy urban population. Therefore, it is suggested that local administrations, park managers and city planners 
design parks that allow visitors to participate in various physical activities and which can make them feel satisfied with these activities.

\section{Limitations and Suggestions for Further Studies}

This study has some limitations. First, only visitors to parks with physical activity facilities were examined. The results might differ for visitors to parks with different recreational activities. Further studies might be conducted with people who visit neighborhood parks for recreational purposes in order to strengthen the usability and effectiveness of the model used in this study.

Second, the participants of the study consisted of people who visited four neighborhood parks for the purpose of physical activity in the center of Eskişehir, a city located in the west of Turkey. Consequently, the geographical limitation in this study prevents park managers from making inferences for other areas in Turkey. Hence, comprehensive studies should be conducted in cities and towns across Turkey to more widely investigate place satisfaction, revisit intention and place attachment.

Finally, future studies which examine different variables on the basis of the literature would also contribute to the attempts to understand the behaviors of people who visit parks to engage in physical activities. It would then be possible to provide park managers with further valuable information regarding effective park management.

\section{References}

Abou - Shouk, M. A., Zoair, N., El - Barbary, M. N., \& Hewedi, M. M. (2018). Sense of place relationship with tourist satisfaction and intentional revisit: Evidence from Egypt. International Journal of Tourism Research, 20(2), 172-181. https://doi.org/10.1002/jtr.2170

Anderson, J. C., \& Gerbing, D. W. (1988). Structural equation modeling in practice: A review and recommended two-step approach. Psychological Bulletin, 22(2), 72-80. https://doi.org/10.1037/0033-2909.103.3.411

Bagozzi, R. P., \& Yi, Y. (1988). On the evaluation of structural equation models. Journal of the Academy of Marketing Science, 16(1), 74-94. https://doi.org/10.1007/BF02723327

Baran, P., Smith, W., Moore, R., Floyd, M., Bocarro, J., Cosco, N., \& Danninger, T. M. (2014). Park useamong youth and adults: Examination of individual, social, and urban form factors. Environment and Behavior, 46(6), 768-800. https://doi.org/10.1177/0013916512470134

Bedimo-Rung, A. L., Mowen, A. J., \& Cohen, D. A. (2005). The significance of parks to physical activity and public health: a conceptual model. American Journal of Preventive Medicine, 28(2), 159-168. https://doi.org/10.1016/j.amepre.2004.10.024

Bowlby, J. (1969). Attachment and loss (vol. 1. Attachment). New York Basic Books.

Brown, G., Smith, A., \& Assaker, G. (2016). Revisiting the host city: An empirical examination of sport involvement, place attachment, event satisfaction and spectator intentions at the London Olympics. Tourism Management, 55, 160-172. https://doi.org/10.1016/j.tourman.2016.02.010

Browne, M. W., \& Cudeck, R. (1993). Alternative ways of assessing model fit. In K. A. Bollen \& J. S. Long (Eds), Testing Structural Equation Models (pp. 136-162). Newbury Park, CA: Sage.

Budruk, M., \& Stanis, S. A. W. (2013). Place attachment and recreation experience preference: A further exploration of the relationship. Journal of Outdoor Recreation and Tourism, 1, 51-61. https://doi.org/10.1016/j.jort.2013.04.001

Chen, C. F., \& Tsai, D. (2007). How destination image and evaluative factors affect behavioral intentions? Tourism Management, 28(4), 1115-1122. https://doi.org/10.1016/j.tourman.2006.07.007

Chen, N. C., Dwyer, L., \& Firth, T. (2014). Conceptualization and measurement of dimensionality of place attachment. Tourism Analysis, 19, 323-338. https://doi.org/10.3727/108354214X14029467968529

Chen, N. C., Hall, C. M., Yu, K., \& Qian, C. (2019). Environmental Satisfaction, Residential Satisfaction, and Place Attachment: The Cases of Long-Term Residents in Rural and Urban Areas in China. Sustainability, 11(22), 6439. https://doi.org/10.3390/su11226439

Cohen, D. A., McKenzie, T. L., Sehgal, A., Williamson, S., Golinelli, D., \& Lurie, N. (2007). Contribution of public parks to physical activity. American Journal of Public Health, 97, 509-514. https://doi.org/10.2105/AJPH.2005.072447

Dayour, F., \& Adongo, C. (2015). Why they go there: International Tourists' motivations and revisit intention to northern Ghana. American Journal of Tourism Management, 4(1), 7-17. 
Fornell, C., \& Larcker, D. (1981). Evaluating structural equation models with unobservable variables and measurement error. Journal of Marketing Research, 18, 39-50. https://doi.org/10.1177/002224378101800104

Fu, X., Yi, X., Okumus, F., \& Jin, W. (2019). Linking the internal mechanism of exhibition attachment to exhibition satisfaction: A comparison of first-time and repeat attendees. Tourism Management, 72, 92-104. https://doi.org/10.1016/j.tourman.2018.11.002

Fulthorp, K., \& Plunkett, D. (2019). Place Attachment and a Municipal Parks and Recreation Special Event. Event Management, 23(3), 315-327. https://doi.org/10.3727/152599518X15378845225302

George, B. P., \& George, B. P. (2004). Past visits and the intention to revisit a destination: Place attachment as the mediator and novelty seeking as the moderator. Journal of Tourism Studies, 15(2), 51.

Hailu, G., Boxall, P. C., \& McFarlane, B. L. (2005). The influence of place attachment on recreation demand. Journal of Economic Psychology, 26(4), 581-598. https://doi.org/10.1016/j.joep.2004.11.003

Hair, J. F., Black, W. C., Babin, B. J., \& Anderson, R. E. (2013). Multivariate data analysis (7th ed). Harlow Pearson.

Hair, Jr, J. F., Hult, G. T. M., Ringle, C., \& Sarstedt, M. (2016). A Primer on Partial Least Squares Structural Equation Modeling (PLS-SEM). Thousand Oaks: Sage Publications.

Halpenny, E. A. (2006). Environmental behaviour, place attachment and park visitation: a case study of visitors to point pelee national park. Unpublished doctoral dissertation. University of Waterloo, Ontario, Canada.

Halpenny, E. (2010). Pro-environmental behaviors and park visitors: The effect of place attachment. Journal of Environmental Psychology, 30(4), 409-421. https://doi.org/10.1016/j.jenvp.2010.04.006

Han, J. H., Kim, J. S., Lee, C. K., \& Kim, N. (2019). Role of place attachment dimensions in tourists' decision-making process in Cittáslow. Journal of Destination Marketing \& Management, 11, 108-119. https://doi.org/10.1016/j.jdmm.2018.12.008

Hatcher, L. (1994). A Step-by-step Approach to Using the SAS System for Factor Analysis and Structural Equation Modeling. Cary, NC., The SAS Institute.

Hellier, P. K., Geursen, G. M., Carr, R. A., \& Rickard, J. A. (2003). Customer repurchase intention. European Journal of Marketing, 37(11/12), 1762-1800. https://doi.org/10.1108/03090560310495456

Hidalgo, M. C., \& Hernandez, B. (2001). Place attachment: Conceptual and empirical questions. Journal of Environmental Psychology, 21(3), 273-281. https://doi.org/10.1006/jevp.2001.0221

Hosany, S., Prayag, G., Van Der Veen, R., Huang, S., \& Deesilatham, S. (2017). Mediating effects of place attachment and satisfaction on the relationship between tourists' emotions and intention to recommend. Journal of Travel Research, 56(8), 1079-1093. https://doi.org/10.1177/0047287516678088

Hu, B., Tuou, Y., \& Liu, J. (2019). How Does Destination Social Responsibility Impact Residents' Pro-Tourism Behaviors? The Mediating Role of Place Attachment. Sustainability, 11(12), 3373. https://doi.org/10.3390/su11123373

Isa, S. M., Ariyanto, H. H., \& Kiumarsi, S. (2019). The effect of place attachment on visitors' revisit intentions: evidence from Batam. Tourism Geographies, 1-32. https://doi.org/10.1080/14616688.2019.1618902

Kim, B. K., Son, H. G., Lee, M. S., \& Park, I. H. (2011). The Effect of Rural Tourism Village Visitors' Selection Attributes toward Satisfaction and Revisit Intention. Journal of Agricultural Extension \& Community Development, 18(3), 531-550. https://doi.org/10.12653/jecd.2011.18.3.531

Kline, R. B. (2011). Principles and Practice of Structural Equation Modeling (3rd ed.). New York, NY: Guilford Press.

Kuo, L. F. E., Bacaicoa, M., \& Sullivan, W. C. (1998). Transforming Inner-City Landscapes: Trees, Sense of Safety and Preference. Environment and Behavior, 30, 28-59. https://doi.org/10.1177/0013916598301002

Kyle, G., Graefe, A., \& Manning, R. (2005). Testing the dimensionality of place attachment in recreational settings. Environment and Behavior, 37(2), 153-177. https://doi.org/10.1177/0013916504269654

Kyle, G. T., Mowen, A. J., \& Tarrant, M. (2004). Linking place preferences with place meaning: An examination of the relationship between place motivation and place attachment. Journal of Environmental Psychology, 24(4), 439-454. https://doi.org/10.1016/j.jenvp.2004.11.001 
Lai, P., Hsu, Y., \& Nepal, S. (2013). Representing the landscape of Yushan national park. Annals of Tourism Research, 43, 37-57. https://doi.org/10.1016/j.annals.2013.03.004

Lam, D., \& Ozorio, B. (2012). Linking employees' personalities to job loyalty. Annals of Tourism Research, 39(4), 2203-2206. https://doi.org/10.1016/j.annals.2012.07.010

Lee, C., \& Allen, L. (1999). Understanding Individuals' Attachment to Selected Destinations: An Application of Place Attachment. Tourism Analysis, 4(3/4), 173-185.

Lee, J., Kyle, G., \& Scott, D. (2012). The mediating effect of place attachment on the relationship between festival satisfaction and loyalty to the festival hosting destination. Journal of Travel Research, 51(6), 754767. https://doi.org/10.1177/0047287512437859

Lee, T. H., \& Shen, Y. L. (2013). The influence of leisure involvement and place attachment on destination loyalty: Evidence from recreationists walking their dogs in urban parks. Journal of Environmental Psychology, 33, 76-85. https://doi.org/10.1016/j.jenvp.2012.11.002

Loukaitou-Sideris, A., \& Sideris, A. (2010). What brings children to the park? Analysisand measurement of the variables affecting children's use of parks. Journal of the American Planning Association, 76, 89-107. https://doi.org/10.1080/01944360903418338

Loureiro, S. M. C. (2014). The role of the rural tourism experience economy in place attachment and behavioral intentions. International Journal of Hospitality Management, 40, 1-9. https://doi.org/10.1016/j.ijhm.2014.02.010

Low, S. M., \& Altman, I. (1992). Place Attachment: A Conceptual Inquiry. In I. Altman \& S. Low (Eds.), Place Attachment: Human Behavior and Environment (pp. 1-2). New York: Plenum. https://doi.org/10.1007/978-1-4684-8753-4_1

Manzo, L. C., \& Perkins, D. D. (2006). Finding common ground: The importance of place attachment to community participation and planning. Journal of Planning Literature, 20(4), 335-350. https://doi.org/10.1177/0885412205286160

McCormack, G. R., Rock, M., Toohey, A. M., \& Hignell, D. (2010). Characteristics of urban parks associated with park use and physical activity: A review of qualitative research. Health \& Place, 16, 712-726. https://doi.org/10.1016/j.healthplace.2010.03.003

Mesch, G. S., \& Manor, O. (1998). Social Ties, Environmental Perception and Local Attachment. Environment and Behavior, 30(4), 504-519. https://doi.org/10.1177/001391659803000405

Milligan, M. J. (1998). Interactional Past and Potential: The Social Construction of Place Attachment. Symbolic Interaction, 21(1), 1-33. https://doi.org/10.1525/si.1998.21.1.1

Moulay, A., Ujang, N., Maulan, S., \& Ismail, S. (2018). Understanding the process of parks' attachment: Interrelation between place attachment, behavioural tendencies, and the use of public place. City, Culture and Society, 14, 28-36. https://doi.org/10.1016/j.ccs.2017.12.002

Nantel, J., Mathieu, M. E., \& Prince, F. (2011). Physical activity and obesity: biomechanical and physiological key concepts. Journal of Obesity, 2011, 1-10. https://doi.org/10.1155/2011/650230

Oliver, R. L. (1980). A cognitive model of the antecedents and consequences of satisfaction decisions. Journal of Marketing Research, 17(4), 460-469. https://doi.org/10.1177/002224378001700405

Petrick, J. F., Backman, S. J., \& Bixler, R. D. (1999). An Investigation of Selected Factors' Impact on Golfers' Impact on Golfer Satisfaction and Perceived Value. Journal of Park and Recreation Administration, 17(1), $40-59$.

Plunkett, D., Fulthorp, K., \& Paris, C. M. (2019). Examining the relationship between place attachment and behavioral loyalty in an urban park setting. Journal of Outdoor Recreation and Tourism, 25, 36-44. https://doi.org/10.1016/j.jort.2018.11.006

Prayag, G., \& Ryan, C. (2012). Antecedents of tourists' loyalty to Mauritius: The role and influence of destination image, place attachment, personal involvement, and satisfaction. Journal of Travel Research, 51(3), 342-356. https://doi.org/10.1177/0047287511410321

Proshansky, H. (1978). The city and self-identity. Environment and Behavior, 10(2), 147-169. https://doi.org/10.1177/0013916578102002

Ramkissoon, H., \& Mavondo, F. T. (2015). The satisfaction-place attachment relationship: Potential mediators 
and moderators. Journal of Business Research, 68(12), $2593-2602$. https://doi.org/10.1016/j.jbusres.2015.05.002

Ramkissoon, H., Smith, L. D. G., \& Kneebone, S. (2014). Visitor satisfaction and place attachment in national parks. Tourism Analysis, 19(3), 287-300. https://doi.org/10.3727/108354214X14029467968402

Ramkissoon, H., Smith, L. G. D., \& Weiler, B. (2013) Relationship between place attachment, place satisfaction, and pro-environmental behaviour in an Australian national park. Journal of Sustainable Tourism, 21(3), 434-457. https://doi.org/10.1080/09669582.2012.708042

Rastbod, S., \& Aflatounian, Z. (2018). The Relationship Between Place Attachment and the Satisfaction of Visitors in Cinema Multiplex (Case Study: Pardis Melat and koorosh, Tehran, Iran). Space Ontology International Journal, 7(2), 15-21.

Ryan, R. L. (2006). The role of place attachment in sustaining urban parks. In R. H. Platt (Ed.), The Human Metropolis: People and Nature in the 21st-Century City (pp. 61-74). Amherst, MA: University of Massachusetts Press.

Scannell, L., \& Gifford, R. (2010). The relations between natural and civic place attachment and pro-environmental behavior. Journal of Environmental Psychology, 30(3), $289-297$. https://doi.org/10.1016/j.jenvp.2010.01.010

Shonk, D. J., \& Chelladurai, P. (2008). Service quality, satisfaction, and intent to return in event sport tourism. Journal of Sport Management, 22(5), 587-602. https://doi.org/10.1123/jsm.22.5.587

Son, S. M., \& Lee, K. M. (2011). Assessing the influences of festival quality and satisfaction on visitor behavioral intentions. Event $293-303$. https://doi.org/10.3727/152599511X13124625650700

Song, H. M., Kim, K. S., \& Yim, B. H. (2017). The mediating effect of place attachment on the relationship between golf tourism destination image and revisit intention. Asia Pacific Journal of Tourism Research, 22(11), 1182-1193. https://doi.org/10.1080/10941665.2017.1377740

Stedman, R. C. (2002). Toward a social psychology of place: Predicting behavior from place-based cognitions, attitude, and identity. Environment and Behavior, 34(5), 561-581. https://doi.org/10.1177/0013916502034005001

Stokols, D., \& Shumaker, S. A. (1981). People in places: A transactional view of settings. In J. H. Harvey (Ed.), Cognition social behavior and the environment (pp. 441-488). Hillsdale, NJ: Lawrence Erlbaum Associates.

Strzelecka, M., Sorensen, J., \& Wicks, B. E. (2010). The role of place attachment in revitalization of neighborhood parks in East St. Louis. Loisir et Société/Society and Leisure, 33(2), $251-272$. https://doi.org/10.1080/07053436.2010.10707811

Su, W. S., Hsu, C. C., Huang, C. H., \& Chang, L. F. (2018). Setting attributes and revisit intention as mediated by place attachment. Social Behavior and Personality: An International Journal, 46(12), 1967-1981. https://doi.org/10.2224/sbp.6861

Theodorakis, N. D., Alexandris, K., Tsigilis, N., \& Karvounis, S. (2013). Predicting spectators' behavioural intentions in professional football: The role of satisfaction and service quality. Sport Management Review, 16(1), 85-96. https://doi.org/10.1016/j.smr.2012.05.004

Tian-Cole, S., Crompton, J. L., \& Willson, V. L. (2002). An empirical investigation of the relationships between service quality, satisfaction and behavioral intentions among visitors to a wildlife refuge. Journal of Leisure Research, 34(1), 1-24. https://doi.org/10.1080/00222216.2002.11949957

Tuan, Y. F. (1980). Rootedness Versus Sense of Place. Landscape, 24, 3-8.

United Nations, Department of Economic and Social Affairs, Population Division. (2016). The World's Cities in 2016 - Data Booklet (ST/ESA/ SER.A/392).

Uysal, M., Eser, Z., \& Birkan, I. (2002). Measuring visitor satisfaction: an outdoor recreational setting (pp. 279-284). TTRA's 33rd Annual Conference Proceedings. Arlington, VA, USA.

Williams, D. R., Patterson, M. E., Roggenbuck, J. W., \& Watson, A. E. (1992). Beyond the commodity metaphor: Examining emotional and symbolic attachment to place. Leisure Sciences, 14, $29-46$. https://doi.org/10.1080/01490409209513155 
Williams, D. R., \& Roggenbuck, J. W. (1989). Measuring place attachment: Some preliminary results. NRPA Symposium on Leisure Research, San Antonio, TX, USA.

Williams, D. R., \& Vaske, J. J. (2003). The Measurement of Place Attachment: Validity and Generalizability of Psychometric Approach. Forest Science, 49(6), 830-840. https://doi.org/10.1093/forestscience/49.6.830

Wu, H. C., Li, M. Y., \& Li, T. (2018). A study of experiential quality, experiential value, experiential satisfaction, theme park image, and revisit intention. Journal of Hospitality \& Tourism Research, 42(1), 26-73. https://doi.org/10.1177/1096348014563396

Xu, Z., \& Zhang, J. (2016). Antecedents and consequences of place attachment: A comparison of Chinese and Western urban tourists in Hangzhou, China. Journal of Destination Marketing \& Management, 5(2), 86-96. https://doi.org/10.1016/j.jdmm.2015.11.003

Yuksel, A., Yuksel, F., \& Bilim, Y. (2010). Destination attachment: Effects on customer satisfaction and cognitive, affective and conative loyalty. Tourism Management, 31, 274-284. https://doi.org/10.1016/j.tourman.2009.03.007

Zenker, S., \& Gollan, T. (2010). Development and Implementation of the Resident Migration Scale (ReMiS): Measuring Success in Place Marketing. In E. H. Witte \& T. Gollan (Eds.), Sozialpsychologie und Ökonomie (pp. 156-172). Lengerich: Pabst Science Publishers.

Zenker, S., \& Rütter, N. (2014). Is satisfaction the key? The role of citizen satisfaction, place attachment and place brand attitude on positive citizenship behavior. Cities, 38, 11-17. https://doi.org/10.1016/j.cities.2013.12.009

\section{Copyrights}

Copyright for this article is retained by the author, with first publication rights granted to the journal.

This is an open-access article distributed under the terms and conditions of the Creative Commons Attribution license (http://creativecommons.org/licenses/by/4.0/). 